\title{
VICE PRESIDENT'S POWER AND ROLE IN INDONESIAN GOVERNMENT POST AMENDMENT 1945 CONSTITUTION
}

\author{
Roziqin \\ Guanghua Law School, Zhejiang University, China \\ Email: 11902038@zju.edu.cn
}

\begin{abstract}
Politicians are fighting over the position of Vice President. However, after becoming Vice President, they could not be active. The Vice President's role is only as a spare tire. Usually, he would only perform ceremonial acts. The exception was different when the Vice President was Mohammad Hata and Muhammad Jusuf Kalla. Therefore, this paper will question: What is the position of the President in the constitutional system? What is the position of the Vice President of Indonesia after the amendment of the 1945 Constitution? Furthermore, how is the role sharing between the President and Vice President of Indonesia? This research uses the library research method, using secondary data. This study uses qualitative data analysis methods in a prescriptive-analytical form. From the research, the writer found that the President is assisted by the Vice President and ministers in carrying out his duties. The President and the Vice President work in a team of a presidential institution. From time to time, the Indonesian Vice President's position has always been the same to assist the President. The Vice President will replace the President if the President is permanently unavailable or temporarily absent. With the Vice President's position who is directly elected by the people in a pair with the President, he/she is a partner, not subordinate to the President. Moreover, due to his/her capacity and support from his/her team, the Vice President must be empowered to benefit the nation and state.
\end{abstract}

Keywords: Vice President, Indonesian Constitutional Law, Presidential System.

\section{INTRODUCTION}

\section{A. Background}

Ahead of the 2019 Presidential and Vice Presidential Elections, supporting parties offered their cadre to incumbent candidate Joko Widodo (Jokowi) to become his Vice President. After choosing Mahfud MD, at the last minute, Jokowi suddenly changed the candidate to Ma'ruf Amin. Amin is a senior cleric from Banten, who was Rais Syuriah (Chief Advisor) of the Executive Board of Nahdlatul Ulama (PBNU) - the largest Islamic organization in Indonesia - as well as the Chairman of the Assembly of Indonesian Cleric (MUI), as a candidate of his Vice President. The public regretted that Ma'ruf Amin was too old. He was 75 when he becomes the candidate of the Vice President. ${ }^{1}$.Both Jokowi and Amin then won the Presidential Election in 2019. After officially taking office, Amin is only often involved in ceremonial activities. For example, in the cabinet forming, Jokowi asked the Vice President to represent him to attend an event in Japan, so he could not involve in cabinet forming.

\footnotetext{
${ }^{1}$ Haluan, "Ma'ruf Amin Wapres Tertua dalam Sejarah Suksesi Kepemimpinan Nasional," (Ma'ruf Amin, the Oldest Vice President in the History of National Leadership Succession) https://haluan.co/article/Maruf-AminWapres-Tertua-dalam-Sejarah-Suksesi-Kepemimpinan-Nasional, accesed September, $30^{\text {th }} 2020$.
} 
Furthermore, the list of candidate ministers came from the supporting party of Jokowi, while he did not recommend the name. ${ }^{2}$ During the Covid-19 pandemic, the Vice President is also not involved in the team handling the pandemic. The President chooses Airlangga Hartarto, his coordinator minister of economics matters, as the team leader. A survey from Akuratpoll Sentra Riset dan Consulting on Agustus 2020 states that the public satisfaction level of Ma'ruf Amin's performance was only 47,5\%.3

As a country that adopts a presidential system, the Indonesian President has a central role in government. How vital the President's position is, Bernand Schwartz stated that the President is "the most powerful elective in the world." 4 The 1945 Constitution also gives a strong position for the President. ${ }^{5}$ According to the Constitution, the President, who is assisted by the Vice President, is the party exercising executive power. Not only helped by the Vice President but also the President right now is assisted by 34 ministers and eight official who has the position as ministers level. He also has 14 outstanding staff, whom 7 of them come from Millenials. Many institutions, which other than ministerial departments, even under his command, including all state-owned enterprises.

The President is a single position, which is filled by one officeholder. With the strong position and power of the President, the position becomes the target of politicians. Apart from the position of President, political parties also targeted the position of Vice President. The 1945 Constitution states that the Vice President's position is to assist the President. ${ }^{6} \mathrm{He} / \mathrm{she}$ will also replace the President when the President dies, resigns, is dismissed, or cannot carry out his obligations during his office term. ${ }^{7}$

The role of the Vice President of Indonesia differs from one another. At the beginning of independence and during the 1945-1949 revolution, Mohammad Hatta, who served as first Vice President, proved to be of a massive role in controlling state administration and economic development and the political field. For example, he could issue Vice President Decree Number X dated Oktober 16, 1945, which changed the National Committee of Indonesia (KNPI) 's role from a part of the Presidential institution to become a legislature. The Decree Number X was followed by Government Decree dated November 3 and November 14, 1945, which asked the public to form a political party. By those decrees, Indonesia changed from a presidential to a parliamentarian system. ${ }^{8}$ Even though the Vice President issued the regulations without President delegation and any ground, the President did not revoke them. ${ }^{9}$ It happened because they could understand their roles. The Vice

\footnotetext{
2 Tirto, "Ma'ruf Amin Klaim Tak Terlibat Penyusunan Kabinet Kerja Jilid II" (Ma'ruf Amin claims he was not involved in the preparation of the second working cabinet), https://tirto.id/maruf-amin-klaim-tak-terlibatpenyusunan-kabinet-kerja-jilid-ii-eeSW, July 23, 2019, accessed accessed September $25^{\text {th }}, 2020$.

${ }^{3}$ Aline, Ke mana Wapres Ma'ruf Amin saat krisis Corona?" Where is the Vice President Ma'ruf Amin during the Corona crisis?, https://www.alinea.id/bisnis/ke-mana-wapres-ma-ruf-amin-saat-krisis-corona-b1ZSa9w7s, 21 August 2020, accessed September 25 th, 2020.

${ }^{4}$ Harun Alrasid (a), "Pemilihan Presiden dan Wakil Presiden dalam Hukum Positif Indonesia" (Election of President and Vice President in Indonesian Positive Law), speech given at the inauguration ceremony for the position of Madaya professor at the UI Faculty of Law, (Depok: Faculty of Law, University of Indonesia, July 29 1995), p. 1.

${ }_{5}^{5}$ Bagir Manan, "Lembaga Kepresidenan" (The Presidency), second printing, (Yogyakarta: FH UII Press, 2003) p. 18-19.

${ }^{6}$ Indonesia (a), the 1945 Constitution of the Republic of Indonesia, Article 4 paragraph (2).

${ }^{7}$ Ibid., Article 8 paragraph (1).

8 Asshiddiqie, Jimly (a), "Pengantar Ilmu Hukum Tata Negara" (an Introduction to Constitutional Law), Secretariat General and Registrar's Office of the Constitutional Court of the Republic of Indonesia, 2006, p. 229

${ }^{9}$ Dian Ayu Firdayanti, Kedudukan dan Kekuasaan Konstitusional Wakil Presiden dalam Sistem Presidensiil (The Position and Constitutional Power of a Vice President in a Presidential System , Jurist-Diction Vol 3 (4) 2020, p. 1563
} 
President issued those decrees because the President was not in the office, and the situation was critical in the revolution era.

The cooperative relationship between the President and the Vice President in the early days of independence was so close that people call them the duumvirate. The two leaders carry out presidential duties by complementing and complimenting each other. Sukarno was a solidarity maker and an accomplished orator who could move the masses. Meanwhile, Hatta was the administrator who was good at handling the administrative matter, and he was an intellectual who expresses his ideas through writing. ${ }^{10}$

However, in the end, the cooperative relationship was in problem due to a mismatch for several reasons. After Hatta resigned in 1956, President Soekarno did not appoint or attempt to replace a new Vice President. He exercised the power of the Old Order with his authoritarian leadership style until he was finally demoted by the Provisional People's Consultative Assembly (MPRS) from President's position.

After President Soekarno's fall, the Old Order ended, and Indonesia entered the New Order under President Soeharto's leadership. In carrying out his duties for 32 years, President Soeharto was assisted by six Vice Presidents in turn and ministers. However, President Soeharto's Vice Presidents' role was less significant and is often seen as just a spare tire. This condition was occurred due to the dominant position of the President. ${ }^{11}$ Even during the early days of President Soeharto's administration, namely 1968-1973, and when he became President's official in 1966, Vice President's position was vacant. ${ }^{12}$

President Soeharto resigned as President on May 21, 1998, after serving as President for 32 years. He left at the pressure of the people who wanted reform. Then began the Reform Order under President Habibie's leadership. When Habibie became President, he did not choose a Vice President and worked only with ministers.

After Habibie, then Abdurrahman Wahid became a President. During Wahid's presidency, there were so many problems to be solved, while President Wahid had a physical disability and would not compromise with political parties. Vice President Megawati Soekarno Putri then turned out to have extensive powers. President Wahid asked her to handle human rights, including conflicts in Irian Jaya (now its name is Papua), Aceh, and Maluku, and environmental problems. ${ }^{13}$ There was even a discourse that the President should only be the head of state, while the head of government was held daily by the Vice President. Some parties wanted to make the People's Consultative Assembly (MPR) Decree specifically regulating the matter to achieve this. ${ }^{14}$ However, President Wahid rejected such discourse.

President Wahid finally issued Presidential Decree Number 121 of 2000 concerning the President's Assignment to the Vice President to Carry Out Daily Government Technical Duties. ${ }^{15}$ The Presidential Decree clearly explained the duties of the Vice President. Those

${ }^{10} \mathrm{R}$ William Liddle, Year One of the Yudoyono-Kalla Duumvirate, Bulletin of Indonesian Economic Studies, 41 (3), p. 323, See also Tempo, Hatta: "Jejak yang Melampaui Zaman,” Traces That Transcend the Ages p. 8

${ }^{11}$ Fajar L Suroso, The Possibility of Vice-Presidents' Authority Arrangement in the 1945 Constitution Throught Constitutional Amendment, Halrev (2): 1, 2016, ,p.. 142

12 Miriam Budiardjo, "Dasar-Dasar Ilmu Politik"(Basics of Political Science), twenty-first printing (Jakarta: Gramedia Pustaka Utama, 2000), p. 221.

13 Suroso, op. cit. p. 143.

14 See, for example, in "Akan Diatur dalam Tap MPR: Abdurrahman Wahid "Digiring" Hanya Untuk Jadi Kepala Negara (Will be Regulated in MPR Decree: Abdurrahman Wahid" Being Led "Only to Become Head of State)," Kompas , (August 9 2000): 1.

15 Indonesia (b), Keputusan Presiden tentang Penugasan Presiden kepada Wakil Presiden untuk Melaksanakan Tugas Teknis Pemerintahan Sehari-hari (Presidential Decree on the Assignment of the President to the Vice President to Carry Out Day-to-Day Government Technical Duties), Presidential Decree No. 121 of 2000. 
duties were: (1) formulating cabinet work programs and agendas and determining the focus and priorities of government policies; (b) chaired a cabinet session, concluded the results, and explained them for the information of all the people; (c) gave direction and instructions to cabinet members; (d). monitored, tested, and assessed cabinet members' work in implementing the cabinet's program and work plan; (e). coordinate with other high state institutions to expedited the task of administering governance; (f). made operational decisions in the context of implementing day-to-day technical government tasks; and (g). signed a decree containing the decision approved by the President. That was the first and the only rule which gives exact duties to the Vice President. Besides, the President issued that decree for long-term responsibilities. It applied from the stipulation date until the end of the President's office for the 1999-2004 period. The other President's orders only set for a limited time when the President is temporarily absent in the office.

However, before the Vice President acted for those extensive duties, President Wahid then was impeached due to political matters. Afterward, Vice President Megawati came to the office replaced him. During the reign of President Megawati Soekarno Putri, Vice President Hamzah Haz did not have a significant role. There was no clear division of duties between the two. This problem also happened during President Susilo Bambang Yudhoyono's term office. There was no special division of tasks for the President and Vice President. However, it turned out that Vice President Muhammad Jusuf Kalla played an essential role in executive leadership. Such roles were issuing the Decree (SK) of Vice President No.1 of 2004 concerning the Aceh National Disaster Management Team's Establishment. Besides, he played an essential role in the negotiation process between the Indonesian government and the Free Aceh Movement, active in national disaster management. He made comments or directions on specific issues.

Through the Secretariat of the Vice President, Kalla had also issued a letter regarding the proposal of several candidates for echelon I officials. They were proposed to the ranks of the ministers. Previously, the Vice President's Secretary had also issued a letter asking the ministers not to consider the importance of a working meeting with the House of Representatives (DPR).

The relationship between President Yudhoyono and Vice President Kalla was often considered in a rivalry. ${ }^{16}$ Controversy in society arose when President Yudhoyono made a teleconference to chair cabinet meeting from abroad, even though he had mandated the Vice President to carry out day-to-day governance during the President's trips abroad. The two leaders' relationship became a debate when the President created the Presidential Work Unit for Program Management and Reform (UKP3R). Some scholars feared UKP3R would reduce the duties, rights, and powers of the Vice President. ${ }^{17}$

During the second term of President Yudhoyono's leadership, he was accompanied by Vice President Budiono. Even though he has Professor's title and previously held a prestigious position as governor of Bank Indonesia, Budiono did not have a significant role when he was Vice President.

The next President is Joko Widodo (Jokowi), who is now entering his second term in office. In the first term, Jokowi was accompanied by Vice President Kalla, while in the second term, Jokowi was accompanied by Amin. Neither Kalla nor Amin played a significant role. Even Kalla, who was very active when accompanying Yudhoyono, did not appear to be prominent in his activities when accompanying Jokowi. Kalla was more involved e as

16 See for example in " Blitzkrieg Jusuf Kalla Berhasil" (Blitzkrieg Jusuf Kalla Succeeded), Kompas, (December 20 2004) : 4.

${ }^{17}$ See for example in "Presiden-Wapres Sepakat Tak Ubah Koordinasi" (President-Vice President Agree Not to Change Coordination), Kompas, (November 4, 2006): 1. 
Chairman of the Indonesian Mosque Council (DMI) and Chairman of the Indonesian Red Cross (PMI). Likewise, Amin, who is an important figure in the field of Islam, did not play a significant role when various Islamic groups demonstrated Jokowi. Even there was a rumor that Amin was asked to represent the President in an overseas event during the cabinet's formation, so he could not join to form the cabinet.

Constitution 1945 does not provide clarity regarding the role of the Vice President. Article 4 paragraph (2) only states that one Vice President assists the President in carrying out his/her obligations. Meanwhile, the duties of the President are regulated quite clearly in the 1945 Constitution. Besides, Article 8 paragraph (2) of the 1945 Constitution states that if the President dies, resigns, is terminated, or is unable to carry out his duties during his term of office, the Vice President replaces him until his term of office.

The Vice President's unclear role often creates debate about the functions of Indonesia Vice President. Some parties want the position of the Vice President to be clarified in the Presidential Law. The law needs to explain some essential clauses, including the relationship and the role's division between the President and the Vice President. ${ }^{18}$ However, some others reject it; ${ }^{19}$ the law has not yet been completed and is still a Draft Law even though it has been discussed since Wahid's presidency.

Thus, the role of the Vice President in Indonesia remains unclear. Therefore, this research will discuss further the position and role of the Vice President after the amendment of the 1945 Constitution. The discussion focused after the 1945 Constitution Amendment, to see whether the Vice President, who was elected in a pair with the President, has a different role and position than before the amendment. Indonesia amended the 1945 Constitution four times to fulfill the political aspirations of the people. The amendments were made in 1999, 2000, 2001, and 2002. Although the last amendment was in 2002, experts still call it the 1945 Constitution, the year when the first Constitution was formed in Indonesia.

\section{B. Research Question}

Based on this background, the main problems in this research are what is the position of the President in the constitutional system? What is the position of the Indonesian Vice President of Indonesia after the 1945 Constitution amendment? And how are the role sharing between the President and Vice President of Indonesia?

\section{Theoretical Review}

\section{Presidential System}

Presidential systems are often seen as part of the separation of powers theory popular in the eighteenth century when the United States Constitution was drafted. One of the scholars who focus on this issue is John Locke. In the late seventeenth century, John Locke suggested that the long conflict between the British monarchy and Parliament should be resolved by separating the king's powers from the two chambers of Parliament as the

18 See for example Saldi Isra (a), " UU Kepresidenan Suatu Keniscayaan" (The Presidential Law is a necessity), Kompas, (January 25 2005) : 8, RUU Kepresidenan Sudah Jadi Prioritas Badan Legislasi (the Presidential Bill is a Priority for the Legislation Body," Kompas, (January 27 2005): 8," Peranan Wakil Presiden Perlu Diatur Dengan UU, (The Role of the Vice President Needs to Be Regulated By Law), "Kompas, (April 3 2003): 6.

${ }^{19}$ See, for example, Maria Farida Indriati, " Kepresidenan Bukan Materi Muatan UU (Presidency is not a matter for laws)," Kompas , (February 112005$): 4$. 
legislature. The model and prototype of a presidential system of Government in the United States. ${ }^{20}$

An effective presidential system is used to ensure a healthy and effective system of government. In a presidential system, the head of state's position is not separated from the head of the government's position, so that only one type of executive is known. The functions of the head of government (chief of the executive) and head of state ( head of state) are in one hand and single ( single executive), namely the President as the sole executive power holder. The cabinet is responsible to the President as the holder of state government power or as the highest administrator. ${ }^{21}$ As a chief executive, the President appoints his ministers to lead their respective departments, and they are only responsible to the President. Since the formation of a cabinet is independent and does not require Parliament's approval, Parliament cannot dismiss ministers. ${ }^{22}$

To avoid power centralization in one person, some countries use a semi-presidential system. The semi-presidential system has some characteristic, among others are (1) there are two executives: a President and a Prime Minister who share executive authority; (2) a President has power as a head of state (3) a President directly elected by a popular vote and serve in a fixed term; (4) the Prime Minister and government hold a governing mandate from and are accountable to the legislature. ${ }^{23}$ The semi-presidential system is a bridge between the presidential and parliamentarian system. A semi-presidential system can minimize potential presidential dictatorship. ${ }^{24}$

\section{The President}

The word president is a derivative of to preside, means leading or appearing at the front. In comparison, the Latin word presidere comes from prae, which means in front, and the word sedere, which means sitting. ${ }^{25}$ In simple terms, we can define the President as the chief executive at a Republic, the chief officer of a branch of government, or the country's chief executive.

The presidential institution in the state administration is related to the form of the Republic. The Vice President's primary function is to assume the President's office if that position is vacant. The vacancy comes from death, resignation, impeachment, or disability). ${ }^{26}$ The Vice President position is important if we learn from many countries' experiences. For example, in the United States from 1841 to 1975 , one-third of presidents did not complete their term to the office and replaced their Vice Presidents. The Vice Presidents also assume the office of presidents in Brazil (1992), Filipina (2001), Bolivia (2001), Botswana (1998),

20 Douglas V Verney, "Parliamentary Government and Presidential Government," in Arend Lijphart, Parliamentary Versus Presidential Government, fifth edition, (New York: Oxford University, 1998), p. 38-39.

21 Jimly Asshiddiqie (b), "Perkembangan dan Konsolidasi Lembaga Negara Pasca Reformasi (Post-Reform Development and Consolidation of State Institutions)", (Jakarta: Secretariat General and Registrar's Office of the Constitutional Court of the Republic of Indonesia, 2006) , p. 60.

22 Moh. Kusnardi and Harmailly Ibrahim, Pengantar Hukum Tata Negara Indonesia (Introduction to the Indonesian Constitutional Law”, sixth mold, (Jakarta: Center for Constitutional Law, Faculty of Law, University of Indonesia, 1985) , p. 176

${ }^{23}$ Richard Stacey and Sujit Choudhry, Semi-Presidential Government in the Post Authoritarian Context, Center for Constitutional Transition at NYU Law, 2014.

${ }^{24}$ Ibid. p. 13

${ }^{25}$ Harun Alrasid (b), "Pengisian Jabatan Presiden" (Filling the Position of President), (Jakarta: Pustaka Utama Grafiti, 1999), p. 10.

${ }^{26}$ Jody C Baumgartner, and Rhonda Evans Case, Constitutional Design of the Executive: Vice Presidencies in Comparative Perspective, https://doi.org/10.1080/07343460902948105, 36: 2, p. 151 
and Indonesia (2001). ${ }^{27}$ Based on Baumgartner and Case's dataset, ${ }^{28}$ among democratic countries, 170 of them have presidents, and 37 of them have Vice Presidents. Eight of the countries with Vice Presidents have dual executive, the President, and the Prime Minister. Some republic countries have two Vice Presidents such as Peru, Costa Rica, Panama, Zimbabwe, while Honduras has three Vice Presidents. Some countries newly implemented Vice President office, like Colombia(2005) and Dominical Republic (2002), while others have long experience in implementing vice presidencies, such as the United States (1787) and Switzerland (1874).

Baumgartner and case ${ }^{29}$ also show that the functions of Vice Presidents are varying in many countries. In some countries, like Argentina, Uruguay, Bolivia, and Zimbabwe, they use the United States model to have legislative functions with or without the voting right. Meanwhile, some countries, like Cyprus, Venezuela, Botswana, Paraguay, Venezuela, Zimbabwe, Philippines, Brazil, and Indonesia, assign their Vice President in executive functions.

\section{RESEARCH METHODS}

This research uses the library research method. This study will analyze the object of research using secondary data. This study uses qualitative data analysis methods in a prescriptive-analytical form.

\section{RESEARCH FINDINGS}

\section{A. The position of the President In the Political System}

The office of President first appeared in the United States in the 18th century. It can be seen from the Constitution drafted by the Federal convention in 1787. "The executive power shall be vested in a President of the United States of America. ${ }^{30}$

The framework of thought that underlies the government's presidential system's application has developed most recently after human history has experienced ups and downs of developments in administering state power. In the early stages, state power was organized absolutely in the King, Queen, or other terms. In the second stage, the power system centered in the king's hands then was deconcentrated to the Prime Minister. The history then introduces constitutional concepts such as constitutional monarchy, democratic monarchy, and many others. At a later stage, the king's power was not only reduced or deconcentrated but also the royal institutions themselves were removed and replaced by a democratically elected president. Usually, the President is accompanied by one or more Vice Presidents. However, there is no Vice President in the parliamentary system.

In the United States, as a country adopt the presidential system, the President is accompanied by the Vice President. Both are chosen for the same term. The Vice President has a formal duty to preside over the Senate, though he does not participate in its

\footnotetext{
${ }^{27}$ Ibid., p 149 see also Jimly Asshiddiqie (c) , Format Kelembagaan Negara dan Pergeseran Kekuasaan Dalam UUD 1945 (Format of State Institutions and the Power Shifting in the 1945 Constitution), second edition (Yogyakarta: FH UII Press, 2005 , p. 59

${ }^{28}$ Baumgartner, and Case, op. cit, p. 153

${ }^{29}$ Ibid, p. 153-158.

${ }^{30}$ Alrasid (b), op. cit., p. 10.
} 
deliberations. ${ }^{31}$ In case of removing the President from office or of his death or resignation, the Vice President shall become President. ${ }^{32}$

In Egypt, which adopts a semi-presidential system, it has dual executive: a President serves as Head of State, while a Prime Minister serves as head of government. ${ }^{33}$ Previously, Egypt had two Vice Presidents ${ }^{34}$, but the 2012 constitution abolished it.

The President is elected by direct secret ballot, with an absolute majority of valid votes. ${ }^{35}$ President, the Cabinet, and every member of the House of Representatives has the right to propose laws. ${ }^{36}$ The President also has the right to issue or object to laws. ${ }^{37}$ However, the President may not dissolve the House of Representatives except when necessary by a causal decision and following a public referendum. ${ }^{38}$

In Egypt, the President assigns a Prime Minister to form the government and present his program to the House of Representatives. ${ }^{39}$ The President may delegate some of his authorities to the Prime Minister, deputies, the ministers, or the governors. ${ }^{40}$ The House of Representatives may decide to withdraw its confidence from the Prime Minister, a deputy of the Prime Minister, ministers, or deputies. ${ }^{41}$ If, on account of a temporary impediment, the President of the Republic is rendered unable to carry out the presidential functions, the Prime Minister acts in his place. ${ }^{42}$

In Singapore, a country that adopts a parliamentary system, the President is the head of state, ${ }^{43}$ while the Prime Minister acts as head of government. The President is to be elected by the Singapore citizens. ${ }^{44}$ The President must not be a member of any political party and neither a member of Parliament. ${ }^{45}$ The President appoints a Member of Parliament as a Prime Minister. With the Prime Minister's advice, the President appoints other Ministers from among the Members of Parliament. ${ }^{46}$ The President needs to consult the Prime Minister to select the President's personal office. If President vacant, the Prime Minister acts as a President. ${ }^{47}$ Meanwhile, the President authorizes other ministers to exercise the Prime Minister's function when he/she is absent from his duties. ${ }^{48}$ The Prime Minister may advise the President to dissolve the Parliament.

In the 1945 Constitution, the presidential institution has pervasive power. As a high state institution, the President's position in the state government is crucial because he holds extensive power. The President of Indonesia is the Head of State and the Head of Government. As the leader of the government, ${ }^{49}$ he may establish Government Regulations. He holds the highest power over the Army, Navy, and Air Force. He has the right to submit a

31 The United State Constitution, Article 1 Section 3. See also The American Presidency, Encyclopedia Britanica, Inc, 2009, p 2

${ }^{32}$ The United State Constitution, Amendment XXV Section 1

${ }^{33}$ Egypt Constitution of 2014, Article 139 and 163. See also Baumgartner and Case, op. cit., p. 153

${ }^{34}$ Asshiddiqie (c ), op. cit., p. 63.

35 Egypt Constitution of 2014, Article 143.

36 Ibid, Article 122 paragraph (1).

${ }^{37} \mathrm{Ibid}$, Article 123 paragraph (1).

38 Ibid, Article 137 paragraph (1).

39 Ibid, Article 146.

40 Ibid, Article 148.

${ }^{41} \mathrm{Ibid}$, Article 131

${ }^{42}$ Ibid, Article 160.

${ }^{43}$ Singapore Constitution, Article 17.

${ }^{44}$ Ibid, Article 17A.

${ }^{45} \mathrm{Ibid}$, Article 19A.

${ }^{46} \mathrm{Ibid}$, Article 25.

${ }^{47} \mathrm{Ibid}$, Article 22L.

${ }^{48} \mathrm{Ibid}$, Article 26 paragraph 4a.

${ }^{49}$ Indonesia (a), op. cit., Article 4. 
draft of the law and discuss it with the Parliament. ${ }^{50}$ With the Parliament's approval, the President may declare peace, make agreements with other countries ${ }^{51}$, and other international agreements that have broad and fundamental consequences for the people..$^{52}$ The President must also ask the Parliament for consideration in appointing ambassadors, accepting ambassadors' assignments from other countries, and providing amnesty and abolition. ${ }^{53}$ Also, the President must also pay attention to the Supreme Court's considerations in granting amnesty and rehabilitation. ${ }^{54}$

After the Amendment to the 1945 Constitution, the President can form a council that gives the President advice and considerations. ${ }^{55}$ The President is also authorized to submit the State Revenue and Expenditure Budget (APBN) Bill to Parliament, ${ }^{56}$ inaugurating the State Audit Intitution (BPK) members who are elected by the DPR with due observance of the DPD's considerations, assigning supreme judges to be proposed by the Judicial Commission (KY) to The DPR, appoints and dismisses members of the Judicial Commission with the approval of the DPR, and determines nine members of constitutional judges who are nominated by three people by the Supreme Court, three by the DPR, and three by the President.

In exercising his power, the President is assisted by the Vice President. ${ }^{57}$ The Vice President's position is also important that AK Pringgodigdo stated that the Vice President is the second President. The President and the Vice President are inseparable institutions, and usually, they are jointly elected. ${ }^{58}$

\section{B. Position of the Vice President of the Republic of Indonesia in 1945 Constitution Post Amendment}

The Vice President's position in the Constitution post amendment does not change, except in the case of replacing the President. In article 8, paragraph (1), The third amendment of the 1945 Constitution is added with one word "dismissed," meaning that if the President is dismissed, the Vice President will replace the President's position as Head of State and Head of Government. The Vice President will replace the President if the President dies, resigns, is dismissed, or is unable to carry out his obligations during his term of office.

After the Amendment, Article 6A Paragraph (1) of the 1945 Constitution stated that the President and Vice President are jointly directly elected in a pair in Presidential and Vice Presidential election. By being directly elected, the presidential institution will become a mighty institution because of its mandate and authority. The President to govern, including forming the cabinet, is no longer obtained from the Parliament, but directly from the people so that the President and the Vice President get powerful political legitimacy. ${ }^{59}$

The President and Vice President's election in a pair indicates that the President and Vice President's positions are among the presidential institutions. However, although in one

\footnotetext{
${ }^{50}$ Ibid., Article 5 paragraph (1), and Article 20 paragraph (1).

${ }^{51}$ Ibid., Article 11 paragraph (1).

52 Ibid., Article 5 paragraph (1), and Article 11 paragraph (2).

53 Ibid., Article 14 paragraph (2).

${ }^{54}$ Ibid., Article 14 paragraph (1).

55 Ibid., Article 16.

56 Ibid., Article 23 paragraph (2).

${ }^{57}$ Ibid, op. cit., Article 4 paragraph (2).

${ }^{58}$ Asshiddiqie ( c), op. cit., p. 63.

${ }^{59}$ Benny K Harman, " Presiden Versus Parlemen (President Versus Parliament)," Kompas , (May 62004$)$ : 4.
} 
presidential institution, they are two separate in constitutional offices and must be distinguished. ${ }^{60}$

If the Vice President becomes vacant, within sixty days at the latest, the MPR will hold a session to elect the Vice President from the two candidates proposed by the President. ${ }^{61}$ Thus, under Article 3 of the Third Amendment of the 1945 Constitution, the MPR only inaugurates the President /Vice President and no longer has the authority to elect the President/Vice President.

The Vice President position's importance is reflected in the draft of the Constitution prepared by the Investigative Body for the Preparation for Indonesian Independence (BPUPKI), which drafted the existence of two Vice Presidents ${ }^{62}$ as the assistant to the President. However, this provision was abolished at the last minute on August 18,1945 , so there was only one Vice President because it would be more efficient. ${ }^{63}$ In the history of state administration, Indonesia had two Deputy Prime Ministers. ${ }^{64}$,

Regarding the Vice President's position and duties, Article 4 paragraph (2) of the 1945 Constitution only states that in carrying out his duties, the President is assisted by one Vice President. However, the term "assist" can lead to various interpretations because Article 17 also states that in carrying out his duties, the President is assisted by ministers (paragraph 1) who lead government departments (paragraph 3). Seen from this point of view, ministers' actual positions, duties, and responsibilities are more exact and more tangible than the Vice Presidents. Ministers exercise government power (pouvoir executive) in practice by leading departments that handle specific problems. ${ }^{65}$ Article 17 of the 1945 Constitution stipulates that the ministers who act as assistants to the President are in charge of the government's specific affairs. ${ }^{66}$

Constitutionally, in his capacity as the President's assistant, the Vice President's position is higher than the minister because the minister is responsible to the President and the Vice President as one institution. ${ }^{67}$ The role of the Vice President then is like a "spare tire." Thus, the Vice President is useful if the way permanently incapacitates the President that the Vice President automatically becomes President.

When the Vice President represents the President, he/she has the same powers as the President and is not limited to some issues. The rationale is that the President is elected jointly with the Vice President, and legal norms regarding the President and Vice President are often mentioned in one breath. ${ }^{68}$

The 1945 Constitution does not regulate the authority of the Vice President while representing the President. Article 4 Paragraph (2) of the 1945 Constitution implies that the Vice President's position is the second person who is almost equal to the President in the Indonesian constitutional system. ${ }^{69}$ In article 8 of the 1945 Constitution, the Vice President's position appears meaningful because it states: if the President dies, resigns, or fails to carry

\footnotetext{
${ }^{60}$ Asshiddiqie ( b ), op. cit., p. 130.

${ }^{61}$ Indonesia (a), op. cit., Article 8 paragraph (2) Third Amendment.

62 Safroedin Bahar and Nannie Hudawati (ed), "Risalah Sidang Badan Penyelidik Usaha-Usaha Persiapan Kemerdekaan Indonesia (Minutes of the Session of the Preparatory Efforts for Indonesian Independence (BPUPKI), Indonesian Independence Preparatory Committee (PPKI) May 28, 1945 - August 22, 1945 , (Jakarta: State Secretariate of Republic of Indonesia, 1998 ), p. 294.

${ }^{63}$ Ibid., P. 533-534.

${ }^{64}$ Asshiddiqie (c ), op. cit., p. 63.

${ }^{65}$ Indonesia (a), op. cit., Article 17 Paragraph (3).

${ }^{66}$ Indriati, loc. cit.

${ }^{67}$ Asshiddiqie ( b), op. cit., p. 131.

${ }^{68}$ Alrasid (b), op. cit., p. 55.

${ }^{69}$ Ibid., P. 85-86.
} 
out his duties during his term of office, he is replaced by the Vice President until his expiration date. It means that as long as the President does not experience these things, during that time, the Vice President only functions to help. However, there are no explicit provisions in what matters or areas he has to help and the extent of authority and responsibility.

As the name implies, the Vice President acts on behalf of the President if the President cannot attend certain activities or does something within the context of his constitutional obligations for reasons that can be justified according to law. In such a case, the Vice President acts as a substitute for the President. Meanwhile, on various other occasions, the Vice President can also act as a companion to the President in carrying out his obligations. ${ }^{70}$

Besides, the Vice President also has a different position as a public official. Thus, the Vice President has five possible positions against the President, namely, a representative who represents the President, a substitute who replaces the President, an assistant who helps the President, an assistant who accompanies the President, and an independent Vice President. In carrying out these positions, the President and Vice President are a unitary legal subject of the presidential institution. ${ }^{71}$

In his position to accompany the President and independently carry out his position, the Vice President does not need the President's approval, instructions, or special assignments. If it is not stipulated otherwise, the Vice President can freely accompany the President or carry out his activities independently in his position as Vice President. ${ }^{72}$

In their capacity as an assistant to the President, the Vice President's assistance can be in the form of assistance provided at the Vice President's initiative, at the request of the President, and assistance provided because a Presidential Decree determines it. ${ }^{73}$

There are fundamental differences in the position of the Vice President as a representative and as a substitute. To represent the President, a Vice President must receive a mandate from the President either directly, officially, or indirectly or informally. The mandate is not absolute and can be withdrawn by the mandate at any time. ${ }^{74}$

This provision differs from the position of the Vice President as a substitute. The Vice President's replacement is carried out because of two possibilities: the President is temporarily unavailable or permanently unable. If the President is temporarily absent, the Vice President must accept official authority in the form of delegation of power in place of a Presidential Decree. If the President is permanently incapacitated, the transfer of power must be carried out using an MPR Decree. ${ }^{75}$

Considering the importance of the Vice President's position, this position must be filled and not left vacant to anticipate all the possibilities that will arise, which will make the President permanently unable to do so. Article 4 Paragraph (2) of the 1945 Constitution stipulates that one Vice President assists the President in carrying out his duties. This provision does not provide further information whether this obligation applies only to the newly elected President or applies to the Vice President who replaces the President's position.

During the early days of Sukarno's administration, the Vice President was given a significant role so that the President and Vice President's positions were almost equal. This is

\footnotetext{
${ }^{70}$ Asshiddiqie ( b ), op. cit., p. 130.

${ }^{71}$ Ibid., P. 130-131.

72 Ibid., P. 131.

73 Ibid., P. 132.

${ }^{74}$ Ibid.

75 Ibid., p. 132-133.
} 
because both were prominent figures at that time, who were united by the community. During Wahid's reign, giving a significant role to the President was due to substantial political pressure considering that the Parliament did not like Wahid and expected a big role for the Vice President. That was because Wahid often dismissed ministers from a party without the party's approval. During the first Yudhoyono term, Yudhoyono gave Kalla a big role because they were the first pair directly elected by the people. Besides, Kalla later became Chairman of the Golkar Party, the bigger party than Yudhoyono's Democrat Party. With Golkar back up in the Parliament, the Yudhoyono's policy more smooth in the parliament discussion. ${ }^{76}$

\section{Roles Sharing of the President and the Vice President}

Through the 1945 Constitution Third Amendment, the Vice President, together with the President, is jointly elected by the people. Elections in such a pair will increase the Vice President's bargaining position against the President because the two of them attain this position through joint efforts. The promotion of a person to be the President cannot be separated from the role of the Vice President candidate. Thus, the impression of a candidate for Vice President was determined mainly by the elected President's recommendation. In practice, the two candidates' share would disappear in the New Order because of the two candidates' share in winning the election. The Vice President will also feel that his position is higher than the state ministers who are also assistants to the President. ${ }^{77}$

Suppose the President and the Vice President are jointly elected directly through general elections. In that case, this does not make the President and the Vice President share power as if they each hold half of government power shares. Their relationship does not have to be debated, even though the people directly elect them. From the start, they are elected respectively as President and as Vice President. In an orderly way, the Vice President's administration only acts as the party representing the President. ${ }^{78}$ In the Indonesian government system, the Vice President's role is solely to assist the President, while the central point of power rests with the President. Suppose there is a division of tasks assigned to the Vice President. In that case, it is no separation or division of powers from the President but the delegation of part of the President's obligations to his Vice President. In contrast, the power remains intact to the President.

However, the role of the Vice President should not be neglected. The role of Vice President Kalla, who is active in accompanying President Yudhoyono, can be used as a model in the division of the roles of the President and Vice President. Although the two of them actively work and share tasks, the division of roles is still within the constitutional framework.

The model of the relationship between the President and the Vice President can also imitate the relationship between President Sukarno and Vice President Hatta in the early days of Indonesian independence. However, both must understand each other and work for Indonesia, not for the interests of themselves and their groups. In this capacity of statehood that can complement each other, these two figures were able to carry this nation safely through crucial phases from the 1945-1949 independence revolution to the 1950-1956 period,

\footnotetext{
${ }^{76}$ Liddle, op.cit., p. 323.

77 Saldi Isra (b), " Sekitar Pengisian Jabatan Wakil Presiden (About Filling the Position of Vice President)," Kompas , (July 252001 ): 4

${ }^{78}$ Indriati, loc. cit.
} 
which was marked by various upheavals as well as conflicts and intense political polarization in society as a result of political parties competing. ${ }^{79}$

President Soekarno and Vice President Hatta's constitutional practice showed that although the President was not permanently incapacitated, the Vice President could carry out governance.$^{80}$ Both in issuing laws and regulations and made announcements, the Vice President's actions were the President's authority. However, considering that at that time the President was temporarily unavailable, the matters issued by the Vice President could be said as (1) Implementation of the duumvirate in state administration practice or (2) Implementation of the functions of the President by the Vice President because the President was temporarily absent. The legal basis of the Vice President's actions is a convention or constitutional custom. They indicate that acts that are not regulated in the 1945 Constitution but do repeatedly are accepted as national convention.

Of course, there will be those who argue that all of Hatta's decisive roles were possible because of Hatta's extraordinary abilities as an intellectual, professional economist, and as a politician. However, it is necessary to remember that those capabilities may only occur if there was a consensus with President Soekarno. ${ }^{81}$

We can use their relations as the ideal pattern of President-Vice President cooperation. Hatta filled Soekarno's weaknesses in state planning and management, while Soekarno's strengths as an accomplished orator filled Hatta's weakness to convince the public.

Furthermore, Hatta's states attitude manship placed Hatta's role and function as an advisor, which was very prominent without reducing Soekarno's role and function as President. Hatta had carried out this role of advising by reminding Soekarno not to be carried away by currents to the left and right. Fourth, although the duumvirate relationship eventually broke apart, it is said that the relationship between the Soekarno family and the Hatta family is still going well and harmoniously.

The President and Vice President's figures are essential as dualities both in a symbolic sense and in a realistic sense. They are filling and completing each party's weaknesses in running the government and implementing cabinet programs and national development programs.

The Vice President's role needs to be affirmed in writing as in President Wahid's era through a Presidential decree. If there is no written decision, it will result in legal uncertainty, as during the Sukarno administration and the first Yudhoyono administration. Without written rules, the Vice President's role must continue to depend on the President's kindness to share power. He must wait for the President to take action. It makes the position of the Vice President seems like a staff of the President. At the end of Sukarno, with Sukarno's dominant role, Hatta felt that he could not do much. Hatta's role was thus seen only in the early days of independence, so he chose to resign when he had political differences with Sukarno and could not advise him. Meanwhile, during the first Yudhoyono era, it seemed as if there were twin suns, between Yudhono and his Vice President, Kalla. That is due to the unclear division of roles for the President and Vice President.

During President Habibie's era, the absence of a Vice President arose from a misconception about the Vice President's responsibilities who only "helped" the President. With the word "assist," it seems that the nature of the Vice President's assistance in following the wishes of the one who will be assisted, namely the President, whether he wants to be assisted or not in carrying out his obligations as President. If he wants to be assisted, he

\footnotetext{
79 Ibid.

${ }^{80}$ Martosukarto, loc. cit.

${ }^{81}$ Ibid.
} 
is entitled to be assisted by one Vice President, whereas if he does not wish to be assisted, Vice President's position can be vacated. That means that the position of Vice President is optional according to this group's opinion. However, that is not a good concept. The Vice President's presence is significant to assist the President in carrying out the President's duties and preparing the worst condition if the President is absent, temporarily, or permanently.

The role of Hamzah Haz, Budiono, Kalla in accompanying President Jokowi, and Maruf Amin all as Vice Presidents are not significant. The Vice President's duties in assisting the President need to be detailed, but not to separate the Head of Government from the Head of State. As adopting a presidential government system, the 1945 Constitution does not recognize or contain the rules for separating the President as Head of State and as Head of Government.

Nowadays, with the position of Vice-President is jointly elected with the President, has an office Secretariat of the Vice President, and supported by five deputies, even accompanied by eight expert staffs, the presence of the Vice President should be empowered to carry out state duties, including giving advice for President and cabinetwork, by request or by his/her initiative.

In carrying out their duties and roles, the President and the Vice President must indeed work together. We have to reconsider the requirement to cooperate between the two, as in the New Order era has. However, we need to remember that the Vice President is not the President's staff, but his/her partner.

From the provisions of the 1945 Constitution definitively in article 4 concerning the Vice President's position in the government, the Vice President can carry out state duties in the executive jointly with the President and does not have a subordinate position to the President a partner. ${ }^{82}$ Both the President and the Vice President are equal partners for the others to deliberate on policies that will be pursued as administrators of the highest state government. They are accountable to the people at the end of their term of office. ${ }^{83}$

Through partnerships in the administration of the highest state government, it is hoped that a mature thought can be obtained in determining a policy whose field is vast. Differences between each partner are not eliminated, but to be discussed for all the people's benefit. ${ }^{84}$

The Vice President's condition can work together with the President to have reasonable goals because the President and Vice President are in one presidential institution, the executive leadership. They must go hand in hand and have the same vision.

Both are not in a competition arena, neither in a head to head position to get the power and public sympathy. The provisions for cooperation can also be understood to make the President and the Vice President in one vision. If they can not cooperate, he/she may create a scenario so that the MPR will impeach the President. ${ }^{85}$

\section{CONCLUSION}

1. Presidential institutions exist in a republican form of government. It consists of the President and the Vice President, both of them work in a team. In carrying out his duties, the President is assisted by the Vice President and ministers.

\footnotetext{
82 Bachrun Martosukarto, " Kemitraan Antara Presiden dan Wakil Presiden (Partnership between President and Vice President)," Kompas, (November 6 1997) : 4.

${ }^{83}$ Ibid .

${ }^{84}$ Ibid .

${ }^{85}$ Isra ( b ), loc. cit.
} 
Vice President's Power And Role In Indonesian Government Post Amendment 1945 Constitution

2. The Indonesian Vice President's position from time to time has always been the same, namely, to assist the President. The Vice President will replace the President if the President is permanently unavailable or temporarily absent. The Vice President has five possible positions toward the President, namely, a representative who represents the President, a substitute who replaces the President, an assistant who helps the President, an assistant who accompanies the President, and as an independent Vice President. In carrying out these positions, the President and Vice President are a unitary legal subject of the presidential institution. The requirements, mechanisms for electing and dismissing the Vice President are always the same as those of the President. That implies the importance of the Vice President's position as the second President. The vital role of the Vice President, like Muhammad Jusuf Kalla after the amendment of the 1945 Constitution, as well as Mohammad Hatta at the beginning of independence, does not violate the Constitution.

3. With the Vice President's position directly elected by the people in a pair with the President, he/she is a partner, not subordinate to the President. Moreover, with the support from his/her Secretariat and staff, the existence of Vice President needed to be empowered to provide benefits for the nation and state.

\section{BIBLIOGRAPHY}

\section{Regulation}

Indonesia (a), the 1945 Constitution of the Republic of Indonesia.

Indonesia (b), Keputusan Presiden tentang Penugasan Presiden kepada Wakil Presiden untuk Melaksanakan Tugas Teknis Pemerintahan Sehari-hari (Presidential Decree on the Assignment of the President to the Vice President to Carry Out Day-to-Day Government Technical Duties), Presidential Decree No. 121 of 2000.

\section{Book/Journal}

Alrasid, Harun (a), Pemilihan Presiden dan Wakil Presiden dalam Hukum Positif Indonesia (Election of President and Vice President in Indonesian Positive Law), speech given at the inauguration ceremony for the position of Professor at the UI Faculty of Law, (Depok: Faculty of Law, University of Indonesia, July 29, 1995).

(b), "Pengisian Jabatan Presiden (Filling the Position of President)", (Jakarta: Pustaka Utama Grafiti, 1999), p. 10.

Asshiddiqie, Jimly (a), "Pengantar Ilmu Hukum Tata Negara" (an Introduction to Constitutional Law), Secretariat General, and Registrar's Office of the Constitutional Court of the Republic of Indonesia, 2006. 
Vice President's Power And Role In Indonesian Government Post Amendment 1945 Constitution

(b). "Perkembangan dan Konsolidasi Lembaga Negara Pasca Reformasi" (Post-Reform Development and Consolidation of State Institutions)" (Jakarta: Secretariat General and Registrar's Office of the Constitutional Court of the Republic of Indonesia, 2006).

(c) , "Format Kelembagaan Negara dan Pergeseran Kekuasaan Dalam

UUD 1945 (Format of State Institutions and the Power Shifting in the 1945 Constitution)," second edition (Yogyakarta: FH UII Press, 2005).

Bahar, Safroedin and Nannie Hudawati (ed), "Risalah Sidang Badan Penyelidik UsahaUsaha Persiapan Kemerdekaan Indonesia (Minutes of the Session of the Preparatory Efforts for Indonesian Independence (BPUPKI), and Indonesian Independence Preparatory Committee (PPKI) May 28, 1945 - August 22, 1945 , (Jakarta: State Secretariate of Republic of Indonesia, 1998 ).

Baumgartner, Jody C, and Rhonda Evans Case, Constitutional Design of the Executive: Vice Presidencies in Comparative Perspective, https://doi.org/10.1080/07343460902948105, 36: $2,148-163$.

Budiardjo, Miriam "Dasar-Dasar Ilmu Politik" (Basics of Political Science), twenty-first printing (Jakarta: Gramedia Pustaka Utama, 2000).Firdayanti, Dian Ayu Kedudukan dan Kekuasaan Konstitusional Wakil Presiden dalam Sistem Presidensiil (The Position and Constitutional Power of a Vice President in a Presidential System , Jurist-Diction Vol 3 (4) 2020, p. 1563

Harman, Benny K. "Presiden Versus Parlemen" (President Versus Parliament), Kompas, (May 6, 2004): 4.

Isra, Saldi (a). "UU Kepresidenan Suatu Keniscayaan" (The Presidential Law is a necessity), Kompas, (January 25 2005): 8, RUU Kepresidenan Sudah Jadi Prioritas Badan Legislasi (the Presidential Bill is a Priority for the Legislation Body," Kompas, (January 27 2005): 8," Peranan Wakil Presiden Perlu Diatur Dengan UU, (The Role of the Vice President Needs to Be Regulated By Law), "Kompas, (April 3 2003).

Isra, Saldi (b). "Sekitar Pengisian Jabatan Wakil Presiden (About Filling the Position of Vice President)," Kompas , (July 25, 2001).

Liddle, R William. Year One of the Yudhoyono-Kalla Duumvirate, Bulletin of Indonesian Economic Studies, Routledge, 41 (3), p. 323-338. DOI: 10.1080/00074910500306593 
Vice President's Power And Role In Indonesian Government Post Amendment 1945 Constitution

Kusnardi, Moh.and Harmailly Ibrahim. Pengantar Hukum Tata Negara Indonesia (Introduction to the Indonesian Constitutional Law", sixth mold, (Jakarta: Center for Constitutional Law, Faculty of Law, University of Indonesia, 1985).

Manan, Bagir. "Lembaga Kepresidenan (The Presidency)”, second printing, (Yogyakarta: FH UII Press, 2003).

Martosukarto, Bachrun. "Kemitraan Antara Presiden dan Wakil Presiden (Partnership between President and Vice President)," Kompas , (November 6 1997).

Suroso, Fajar L The Possibility of Vice-Presidents' Authority Arrangement in the 1945 Constitution Through Constitutional Amendment, Halrev (2): 1, 2016, p.. 142

The American Presidency, Encyclopedia Britanica, Inc, 2009.

Verney, Douglas V. "Parliamentary Government, and Presidential Government," in Arend Lijphart, Parliamentary Versus Presidential Government, fifth edition, (New York: Oxford University, 1998).

\section{Mass Media}

Aline, "Ke mana Wapres Ma'ruf Amin saat krisis Corona?" Where is the Vice President Ma'ruf Amin during the Corona crisis?, https://www.alinea.id/bisnis/ke-mana-wapresma-ruf-amin-saat-krisis-corona-b1ZSa9w7s, 21 August 2020, accessed September 25 ${ }^{\text {th }}$, 2020.

Cnn Indonesia, "Mencari Peran Ma'ruf di Tengah Wira-wiri Calon Menteri” (Seeking the Role of Ma'ruf in the Middle of Ministerial Candidates), https://www.cnnindonesia.com/nasional/20191022071406-32-441668/mencari-peranmaruf-di-tengah-wira-wiri-calon-menteri, October 22, 2019, accesed September $25^{\text {th }}$, 2020

Haluan, "Ma'ruf Amin Wapres Tertua dalam Sejarah Suksesi Kepemimpinan Nasional," (Ma'ruf Amin, the Oldest Vice President in the History of National Leadership Succession) https://haluan.co/article/Maruf-Amin-Wapres-Tertua-dalam-SejarahSuksesi-Kepemimpinan-Nasional, accesed September, 30 2020.

Kompas . Maria Farida Indriati, "Kepresidenan Bukan Materi Muatan UU (Presidency is not a matter for laws)," (February 112005$).$

Kompas. "Akan Diatur dalam Tap MPR: Abdurrahman Wahid "Digiring" Hanya Untuk Jadi Kepala Negara" (Will be Regulated in MPR Decree: Abdurrahman Wahid "Being Led" Only to Become Head of State), (August 92000 ). 
Vice President's Power And Role In Indonesian Government Post Amendment 1945 Constitution

Kompas. "Blitzkrieg Jusuf Kalla Berhasil (Blitzkrieg Jusuf Kalla Succeeded)," (December $202004)$.

Kompas. "Presiden-Wapres Sepakat Tak Ubah Koordinasi (President-Vice President Agree Not to Change Coordination," (November 4, 2006).

Kompas. "Kasus Pemecatan Wakil Presiden Rusia Bisa Timbulkan Pergolakan Baru, (The Vice President Dismissal Case Could Cause New Upheavals)," (September 3, 1993).

Tempo, Hatta: “Jejak yang Melampaui Zaman,” (Traces That Transcend the Ages) p. 8

Tirto, "Ma'ruf Amin Klaim Tak Terlibat Penyusunan Kabinet Kerja Jilid II" (Ma'ruf Amin claims he was not involved in the preparation of the second working cabinet), https://tirto.id/maruf-amin-klaim-tak-terlibat-penyusunan-kabinet-kerja-jilid-ii-eeSW, July 23, 2019, accessed accessed September 25 th 2020. 